\title{
In vitro effect of cadmium and copper on separated blood leukocytes of Dicentrarchus labrax
}

\author{
Mirella Vazzana ${ }^{\mathrm{a}}$, Monica Celi ${ }^{\mathrm{a}}$, Cecilia Tramati ${ }^{\mathrm{b}}$, Vincenzo Ferrantelli ${ }^{\mathrm{c}}$, \\ Vincenzo Arizza ${ }^{a, *}$, Nicolò Parrinello ${ }^{a}$ \\ a Dipartimento STEBICEF, Università degli Studi di Palermo,Via Archirafi 18, Palermo, Italy \\ b Dipartimento DISTEM, Università degli Studi di Palermo, Via Archirafi 18, Palermo, Italy \\ c Istituto Zooprofilattico della Sicilia "A. Mirri”, Palermo, Italy
}

\section{A R T I C L E I N F O}

Article history:

Received 26 August 2013

Received in revised form

10 January 2014

Accepted 13 January 2014

\section{Keywords:}

Heavy metal

Leukocytes

NR

MTT

Hsp70 gene

Real-time-PCR

\begin{abstract}
A B S T R A C T
The immunotoxic effects of heavy metals on blood leukocytes of sea bass (Dicentrarchus labrax) were examined. The cells, separated by a discontinuous Percoll-gradients, were exposed in vitro to various sublethal concentrations of cadmium and copper $\left(10^{-7} \mathrm{M}, 10^{-5} \mathrm{M}\right.$, and $\left.10^{-3} \mathrm{M}\right)$ and their immunotoxic effect was then evaluated by measuring neutral red uptake, MTT assay, DNA fragmentation and Hsp70 gene expression. First of all, we demonstrated that the cells treated in vitro could incorporate $\mathrm{Cd}$ and $\mathrm{Cu}$. A relationship between heavy metal exposure and dose-time-dependent alterations in responses of leukocytes from blood was found for both metals, but copper was more immunotoxic than cadmium in all assays performed. A significant reduction in the cells' ability to uptake neutral red and viability by MTT assay was recorded, indicating that both cadmium and copper could change the membrane permeability, inducing cellular apoptosis when the concentration of metals reached $10^{-3} \mathrm{M}$. The apoptotic effect may also explain the high level of cytotoxicity found when the leukocytes were exposed to higher concentration of metals. These results demonstrated that toxic effect of copper and cadmium affect on the mechanisms of cellmediated immunity reducing the immune defences of the organism.
\end{abstract}

c 2014 Elsevier Inc. All rights reserved.

\section{Introduction}

In recent years a great deal of effort has been directed towards elucidating the possible correlation between environmental pollutants and stress-related disease conditions in animals. Industrial development has caused an increase of metal emissions and aquatic environments have been continuously contaminated by so-called heavy metals. They usually occur in a highly soluble form when present in seawater, and their uptake and accumulation are therefore usually proportional to the concentration. Among these metals, copper $(\mathrm{Cu})$ and cadmium (Cd) are of particular importance for their harmful effects on fish. Chronic contamination in the marine environment produces severe problems, especially because these pollutants persist in the environment, and fish show the ability to absorb and accumulate - through the gill surface and gut - higher levels of heavy metals in their tissue than the level of toxic concentration in their environment (Alyakoob et al., 1994), with a consequent negative influence on their homeostatic mechanisms.

\footnotetext{
* Corresponding author.

E-mail address: vincenzo.arizza@unipa.it (V. Arizza).
}

Although copper is essential for cellular metabolism, it becomes extremely toxic at high concentration (Carvalho and Fernandes, 2006). Many papers describe its toxic effect on DNA and the damage to and inhibition of relative repair mechanisms (Emmanouil et al., 2007; Joseph, 2009; Pruski and Dixon, 2002), and the general reduction of protein synthesis coupled with an increase in stress proteins (Qian et al., 2012; Said Ali et al., 2010). Cadmium, whose effects in sublethal concentrations on fish metabolism are well known, has been shown to alter the structure and to cause morpho-pathological changes of varying severity in various organs (Atif et al., 2005; Thophon et al., 2003).

The exposure of fish to sublethal doses of $\mathrm{Cd}$ and $\mathrm{Cu}$ altered the macrophage functions such as phagocytic activity and production of free radicals (Elsasser et al., 1986; Zelikoff, 1993), respiratory burst (Sanchez-Dardon et al., 1999) and the blastogenic and antibody-production responses of lymphocytes (Anderson et al., 1989; O'Neill, 1981; Thuvander, 1989). The effects of metal also affect the levels of circulating leukocytes, thus altering the blood cell ratios (Dick and Dixon, 1985; Murad and Houston, 1988; Nussey et al., 1995). Since leukocytes, through their elevated phagocytic activity, are important to protect the body against bacterial infection, the alteration of their ratio could have deleterious effects on both specific and cellular immune responses. 
In previous papers, Dicentrarchus labrax was used as model organism to investigate the immunotoxic effects of xenobiotics. When a mixture of cadmium and benzo(a)pyrene was injected in the fish body, it reduced phagocytosis both in spleen and kidney macrophages (Lemairegony et al., 1995). Copper and cadmium were shown to have an in vivo inhibitory toxic effect on the phagocytosis and on the production of reactive oxygen intermediates from macrophages from the anterior kidney of sea bass (Bennani et al., 1996).

Previously we observed that all the blood cells of D. labrax exposed to cadmium and copper were affected in their functional responses, including the reduced capability of lysosomes to retain neutral red and the reduced capability of mitochondria to effect enzymatic conversion of MTT (Celi et al., 2008; Vazzana et al., 2009). The aim of this study was to evaluate the impact of cadmium chloride $\left(\mathrm{CdCl}_{2}\right)$ and copper sulfate $\left(\mathrm{CuSO}_{4}\right)$ on leukocytes isolated from $D$. labrax blood cells at different concentrations after 2 and $24 \mathrm{~h}$ of exposure. We measured metal accumulation in the cells by mass spectrometer and the varying effects of toxicity by neutral red uptake and MTT assays. Moreover, we evaluated DNA integrity and Hsp70 gene expression levels by RT-PCR analysis.

\section{Materials and methods}

\subsection{Procedures related to fish and bleeding}

A total of 32 sea bass (D. labrax) weighing 200-250 g were obtained from a commercial fish farm (Ecoittica, TP) were utilized for all the experiments. The fish were acclimated in the department aquaria at constant environmental conditions for at least 2 weeks, and fed with commercial pellets (Biomar for sea bass).

Before sampling, the fish were anesthetized with 0.05 percent MS222 (3-aminobenzoic acid ethyl ester) (Sigma-Aldrich Corp. St Louis, MO, U.S.A.) in seawater.

Blood was collected from the heart into a sterile plastic syringe containing $0.2 \mathrm{ml}$ of heparin and diluted with three shares of cold medium (Leibovitz L15 medium, 100 units penicillin $\mathrm{ml}^{-1}, 100$ units streptomycin/ml and 10 units heparin/ml). Culture medium components were from Gibco Carlsbad, CA, U.S.A. The medium osmolarity was measured by an osmometer (Röebling) and adjusted to that of fish serum $(370 \pm 20 \mathrm{mOsm} / \mathrm{kg})$.

All experiments were performed in full compliance with the national rules and guidelines (D. Lgs 116/92 and subsequent amendments) and international European Commission Recommendation guidelines for the accommodation and care of animals used for experimental and other scientific purposes (2007/526/EC).

\subsection{Density gradient separation of the cells}

Blood samples of 32 individuals were diluted 1:3 with Hanks balanced salt solution (HBSS: $\mathrm{NaCl} 190 \mathrm{mM}$, KCl $5.36 \mathrm{mM}$, glucose $5.54 \mathrm{mM}, \mathrm{KH}_{2} \mathrm{PO}_{4} 0.44 \mathrm{mM}$, $\mathrm{Na}_{2} \mathrm{HPO}_{4} 0.56 \mathrm{mM} ; \mathrm{pH} 7.6,370 \mathrm{mOsm} / \mathrm{kg}$ ) and to separate leukocytes, the total blood cell suspension was layered on a 34-46 percent discontinuous Percoll/ density gradient as previously described (Vazzana et al., 2003). After centrifugation at $400 \times \mathrm{g}$ for $25 \mathrm{~min}$ at $4{ }^{\circ} \mathrm{C}$, a cellular band, enriched in leukocytes, was visible at the interface of the two Percoll gradients and after collection, the cells were washed twice with HBSS. The cellular debris was located at the top of the gradient and the erythrocyte pellet was packed at the bottom. The leukocyte band was counted in a haemocytometer and resuspended at $2 \times 10^{6}$ cells $/ \mathrm{ml}$ in HBSS. Cell viability was determined using a Trypan blue ( 0.01 percent in HBSS $)$ exclusion test.

\subsection{Copper and cadmium exposure}

For experimental purpose, enriched leukocytes from 32 fish were suspended in HBSS at a concentration of $2 \times 10^{7} / \mathrm{ml}$ and aliquots of $200 \mu \mathrm{l}$, per well in double, were seeded in sterile PVC flat bottom 96-well plates. The cells were allowed for $1 \mathrm{~h}$ to adhere to the bottom of the wells to form a monolayer, to which were then added $200 \mu \mathrm{l}$ of $\mathrm{CdCl}_{2}$ or $\mathrm{CuSO}_{4}$ solution at a concentration of $10^{-7} \mathrm{M}, 10^{-5} \mathrm{M}$ and $10^{-3} \mathrm{M}$ or HBSS as control. The cell cultures were incubated in a humidified atmosphere containing 5 percent of $\mathrm{CO}_{2}$ at $18{ }^{\circ} \mathrm{C}$ and sampled at 2 and $24 \mathrm{~h}$

\subsection{Determination of heavy metals in the leukocytes}

After exposure to the metals, the cells- $5 \times 10^{6}$ from nine specimens for each metal standardized concentrations - were mineralized with $5 \mathrm{ml}$ of $\mathrm{HNO}_{3} \mathrm{Suprapur}$
(67-70 percent), $1 \mathrm{ml}$ of $\mathrm{H}_{2} \mathrm{O}_{2}$ Suprapur (30 percent) and $4 \mathrm{ml}$ of MilliQ water in an automatic microwave digestion system (MARS ${ }^{\mathbb{R}}$ CEM) using for sample digestion the CEM XP1500-Plus high-pressure digestion vessels.

The presence of heavy metals in the leukocytes was evaluated with a spectrometer ICP-OES Varian Vista MPX (Inductively Couplet Plasma-Optical Emission Spectrometer) in according to manufacture instruction. The specific wavelengths $(\lambda)$ used for each element were Cd: $214.439 \mathrm{~nm}$ and $\mathrm{Cu}: 324.754 \mathrm{~nm}$.

Only reagents of Suprapur quality and MilliQ water were used during the laboratory procedures. Results were given in $\mu \mathrm{g} / \mathrm{ml}$ per 1000 cells

\subsection{Neutral red uptake assay}

Neutral red uptake assay (NRU) is used to measure cell viability (Borenfreund and Puerner, 1985). It has been used as an indicator of cytotoxicity in cultures of primary hepatocytes (Fautz et al., 1991) and other cell lines (Morgan et al., 1991). Living cells take up the neutral red, which is concentrated within the lysosomes of cells. Chemicals causing membrane damage inhibit the accumulation of this dye. The amount of dye released from the cells is proportional to their vitality. The NRU evaluation was performed, with slight modification, as previously described (Arizza et al., 2013). The cell monolayers from nine fishes, after treatment with metals, were incubated with $200 \mathrm{\mu l}$ of 0.2 percent neutral red in $\mathrm{HBSS}$ for $2 \mathrm{~h}$ at $18{ }^{\circ} \mathrm{C}$ in double. To minimize crystal formation during the neutral red uptake assay, the dye solution was stirred overnight at $37{ }^{\circ} \mathrm{C}$ and filtered $(0.2 \mu \mathrm{m})$ before use. After the incubation period, the supernatant of cell monolayers containing the neutral red dye was discharged, and each well was carefully rinsed twice with $200 \mu$ l of fresh HBSS. Finally, the neutral red adsorbed by the leukocytes was extracted treating the cellular monolayers with $200 \mu \mathrm{l}$ of ethanol and acetic acid $(1: 1 \mathrm{v} / \mathrm{v})$. After mixing weakly, the absorbance of the extracted dye was read on a Labsystems Uiniskan I microplate reader equipped with a $540 \mathrm{~nm}$ filter. Results from triplicate samples were recorded as the average number of optical density units after subtracting the blanks and as NRU per number of cells.

\subsection{MTT reduction assay}

The MTT (3-(4,5)-dimethylthiazol-2-yl)-2,5-diphenyl tetrazolium bromide) assay is a sensitive and quantitative colorimetric assay that measures the viability of cells based on the cellular uptake of MTT and its subsequent reduction by mitochondrial succinyl dehydrogenase in living cells to convert the yellow substrate into a dark blue formazan product. The original protocol of Mosmann (1983) was optimized for the cells used in these experiments. Briefly, at the end of the incubation time, cells from nine fishes were incubated for $3 \mathrm{~h}$ with $20 \mu \mathrm{l}$ of MTT $(5 \mathrm{mg} / \mathrm{ml})$ in HBSS in double. After incubation the microplates were centrifuged at $500 \mathrm{rpm}$ for $5 \mathrm{~min}$ at $4{ }^{\circ} \mathrm{C}$ and the supernatant of the cell monolayer was aspirated. To extract MTT from the intact cells, $100 \mu \mathrm{l}$ of dimethyl sulfoxide (DMSO) were added and gentle shaking was performed for $10 \mathrm{~min}$. When complete dissolution was achieved aliquots $(100 \mu \mathrm{l})$ of the resulting solutions were transferred into 96well plates and absorbance was recorded at $550 \mathrm{~nm}$ using a Labsystems Uiniskan I microplate reader.

\subsection{Hsp70 gene expression}

\subsubsection{Total RNA extraction and CDNA synthesis}

Total RNA was isolated from the leukocytes, held in RNA later, from every individual by using a RNAqueousTM-Midi Kit purification system (Ambion), and was then reverse-transcribed by the Kit Ready to GoTM T-primed first-strand using random primers (Amersham-Pharmacia Biotech, USA).

\subsection{2. $m R N A$ quantification by real-time quantitative PCR}

Changes in the gene expression of heat shock proteins were quantified using fluorescence real-time quantitative PCR. Analyses were performed in triplicate using a quantitative thermal cycler. Cellular expression of the Hsp70 genes was studied by Real-time PCR using the Taqman method. Primers and hybridization probes were designed using Primer Express software V.0 and synthesized commercially (Applied Biosystems, Foster City, USA). Real-time PCR analysis was performed using the Applied Biosystems 7500 Realtime PCR System, as described previously (Celi et al., 2012). Tissue expression was performed using Hsp70 probe (ACCATGAAGTCCACTGTG), Hsp70 forward (5'-TGGCCTGGAGTCATATGCTTT-3') and reverse (5'-TCTTACCGGCAAGCCTTTCA-3') primers, for housekeeping actin gene probe (ACCACAGCCGAGACG) forward (5'-CAGAGCGTGGCTACTCCTTCA-3') and reverse (5'-TCCTTGATGTCACGCACGAT-3') primers (D. labrax actin Accession number AY148350). For each time point/treatment five individuals were used and each cDNA sample was run in triplicate together with negative controls. The amplification efficiencies of the target and reference genes were approximately equal, thereby validating the $\Delta \Delta C t$ calculation. The amount of Hsp70 transcript from tissue was normalized to actin in order to compensate for variations in input RNA amounts. Relative Hsp70 expression was determined by dividing the normalized value of the target gene in the tissue by the normalized value obtained from untreated tissue. 


\subsection{DNA apoptotic fragment}

DNA was extracted from the cells of five fishes by using the Sigma-Aldrich geneluite mammalian genomic miniprep kit based on a silica-based membrane specially selected for genomic DNA purification, in a convenient spin column format according to the manufacturer's instructions.

Briefly, a suspension of $5 \times 10^{6}$ cells in $200 \mu \mathrm{l}$ of HBSS was prepare and to lyse the cells $20 \mu \mathrm{l}$ of proteinase K, $20 \mu \mathrm{l}$ of RNase and $200 \mu \mathrm{l}$ of lysis buffer (supplied by the kit) were added. After incubation at $70{ }^{\circ} \mathrm{C}$ for $10 \mathrm{~min}, 200 \mu \mathrm{l}$ of 100 percent ethanol were added to the suspension and layered at the top of the column (supplied by the kit), then centrifuged at $6500 \times \mathrm{g}(8000 \mathrm{rpm})$ for $1 \mathrm{~min}$ to remove the medium. The column was washed two times with washing buffer (supplied by the kit) at $12,000 \times \mathrm{g}$ for $3 \mathrm{~min}$. To elute the DNA, the column was treated with eluting buffer (supplied by the kit), incubated for $5 \mathrm{~min}$ at $20{ }^{\circ} \mathrm{C}$ and then centrifuged at $6500 \times \mathrm{g}$. Each eluted sample was analyzed through standard 1 percent agarose gel electrophoresis and visualized with ethidium bromide $\left(5 \mu \mathrm{g} \mathrm{ml}^{-1}\right.$ ) reaction. The DNA fragmentation was analyzed after electrophoresis at 200-BP intervals to check for a "ladder" pattern due to apoptosis. Cellular treatments with $100 \mathrm{mM}$ of 2-deoxy-D-ribose (dRib) were used as a positive control (Malagoli et al., 2005).

\subsection{Statistical analysis}

All experiments were performed three times utilizing for each trial three fish for a total of 27 specimens. For the experiment of Real-time PCR analysis were used a sample size of five fish. Significant differences between values of different incubation groups and the reference control groups were determined with the Statistical analysis by one-way ANOVA with Tukey's post-test.

\section{Results}

\subsection{Leukocytes enrichment}

After density gradient centrifugation, a band enriched mainly with leukocytes was evident at the interface of two gradient steps. It was composed by lymphocytes ( $\sim 59.3$ percent), monocytesmacrophages $(\sim 28.7$ percent), neutrophils ( $\sim 7.1$ percent) and eosinophils ( $\sim 4.9$ percent), thus confirming the results obtained by Vazzana et al. (2003). The viability test, performed on leukocytes after each treatment, showed vitality values greater than 95 percent as determined by trypan blue.

\subsection{Heavy metal analysis}

After exposure to metals, the cells were examined to evaluate the incorporation of $\mathrm{Cd}$ and $\mathrm{Cu}$. The evaluation, performed using a spectrometer ICP-OES, showed that metals were adsorbed by the leukocytes in a dose- and time-dependent manner. Indeed a significant presence of metals was found only after $2 \mathrm{~h}$ of treatment at a concentration of $10^{-5} \mathrm{M}$ for cadmium $(12.6 \mathrm{ng} / \mathrm{ml})$ and for copper $(9.3 \mathrm{ng} / \mathrm{ml})$. The effects were significantly more evident for the higher concentration and exposure time, reaching respectively the values of $386 \mathrm{ng} / \mathrm{ml}$ for $\mathrm{Cd}$ and $456 \mathrm{ng} / \mathrm{ml}$ for $\mathrm{Cu}$ (Table 1). The untreated cells (controls) showed values below of the minimum detectable concentrations of the instrument.

\subsection{NRU assay}

Exposure of leukocytes for different times and at different concentrations of the metals produced a general decrease in the incorporation of neutral red. As shown in Fig. 1a, treatments for $2 \mathrm{~h}$ with $\mathrm{Cd}$ at a concentration of $10^{-5} \mathrm{M}$ significantly reduced $(p<0.01)$ the capability to retain neutral red, and decreased the control value from 0.22 O.D. to 0.15 O.D. While longer treatment $(24 \mathrm{~h})$ significantly decreased $(p<0.01)$ the control value of 0.67 O.D. to 0.18 O.D. at $10^{-7} \mathrm{M}$.

In Fig. 1b are shown the modulating effects of $\mathrm{Cu}$ on NRU. In general, $\mathrm{Cu}$ appeared to have a greater toxic effect than $\mathrm{Cd}$. In fact it showed a significant decrease in retention of neutral red for both
Table 1

Cellular concentration of $\mathrm{Cd}$ and $\mathrm{Cu}$ in separated blood leukocytes of $D$. labrax after $2 \mathrm{~h}$ and $24 \mathrm{~h}$ incubation time.

\begin{tabular}{lcc}
\hline$M$ & $2 \mathrm{~h}$ & $24 \mathrm{~h}$ \\
\hline $\mathrm{CdCl}_{2}$ cellular absorption $(\mathrm{ng} / \mathrm{ml})$ & \\
$10^{-7}$ & $0.1 \pm 0.09$ & $0.1 \pm 0.05$ \\
$10^{-5}$ & $12.6 \pm 0.9$ & $24.4 \pm 1.2^{\mathrm{a}}$ \\
$10^{-3}$ & $262.0 \pm 23.1^{\mathrm{b}}$ & $386.0 \pm 12.5^{\mathrm{c}, \mathrm{d}}$ \\
$\mathrm{CuSO}_{4}$ cellular absorption $(\mathrm{ng} / \mathrm{ml})$ & \\
$10^{-7}$ & $0.3 \pm 0.01$ & $0.3 \pm 0.09$ \\
$10^{-5}$ & $9.3 \pm 0.7$ & $11.7 \pm 0.8^{\mathrm{a}}$ \\
$10^{-3}$ & $371.0 \pm 5.2^{\mathrm{e}}$ & $456.0 \pm 9.6^{\mathrm{f}, \mathrm{d}}$ \\
\hline
\end{tabular}

The values are expressed as $\mathrm{ng} / \mathrm{ml}$ evaluated by a spectrometer ICP-OES. The data are the means of three distinct measures from three separated cell treatments \pm standard deviation. Statistical analysis by one-way ANOVA with Tukey's post-test.

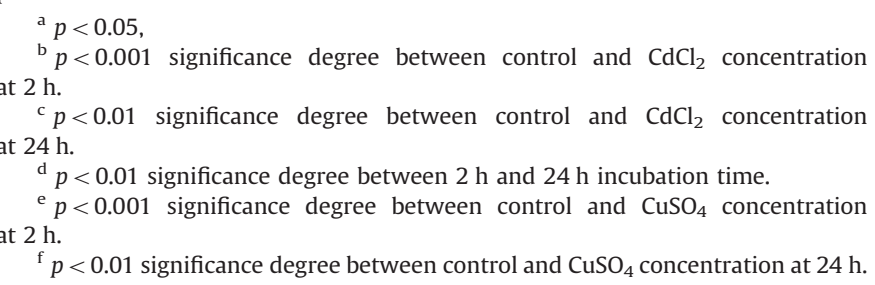

\section{a}

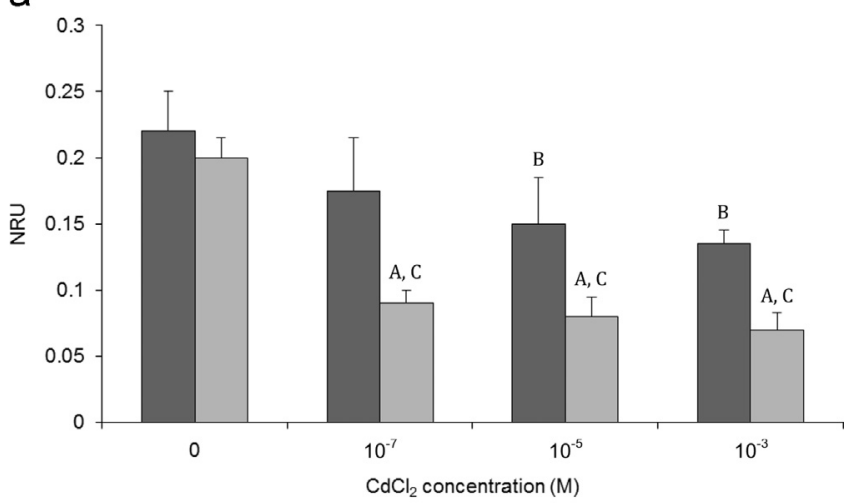

b

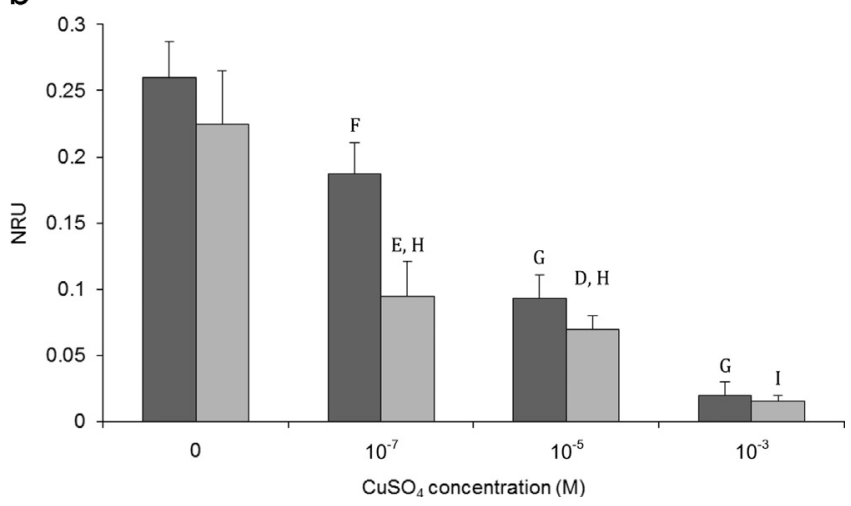

Fig. 1. Neutral red retention activity of separated blood leukocytes of $D$. labrax exposed to $\mathrm{CdCl}_{2}(\mathrm{~A})$ and $\mathrm{CuSO} 4(\mathrm{~B})$ after $\left.2 \mathrm{~h} \mathrm{(}\right)$ and $\left.24 \mathrm{~h} \mathrm{(}\right)$ incubation time. The values are expressed as the optical density of Neutral red retention at $550 \mathrm{~nm}$. Data are the means of three distinct experiments \pm standard deviation. Statistical analysis by one-way ANOVA with Tukey's post-test. $A=p<0.05$ significance degree between $2 \mathrm{~h}$ and $24 \mathrm{~h}$ exposure; $B=p<0.01$ significance degree between control and $\mathrm{CdCl}_{2}$ concentration at $2 \mathrm{~h}$. $C=p<0.01$ significance degree between control and $\mathrm{CdCl}_{2}$ concentration at $24 \mathrm{~h} ; D=p<0.05$ and $E=p<0.001$ significance degree between $2 \mathrm{~h}$ and $24 \mathrm{~h}$ exposure to $\mathrm{CuSO}_{4} ; \mathrm{F}=p<0.05$ and $\mathrm{G}=p<0.001$ significance degree between control and $\mathrm{CuSO}_{4}$ concentration at $2 \mathrm{~h}$; and $H=p<0.01$ and $I=p<0.001$ significance degree between control and $\mathrm{CuSO}_{4}$ concentration at $24 \mathrm{~h}$. 
a

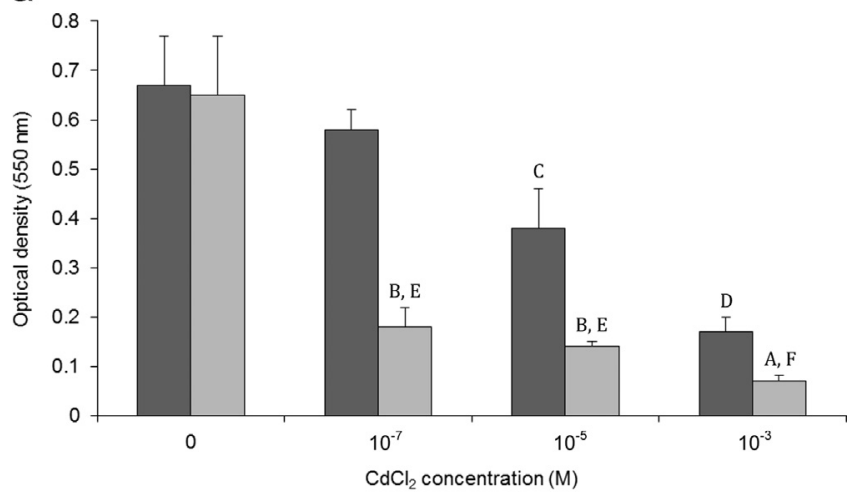

b

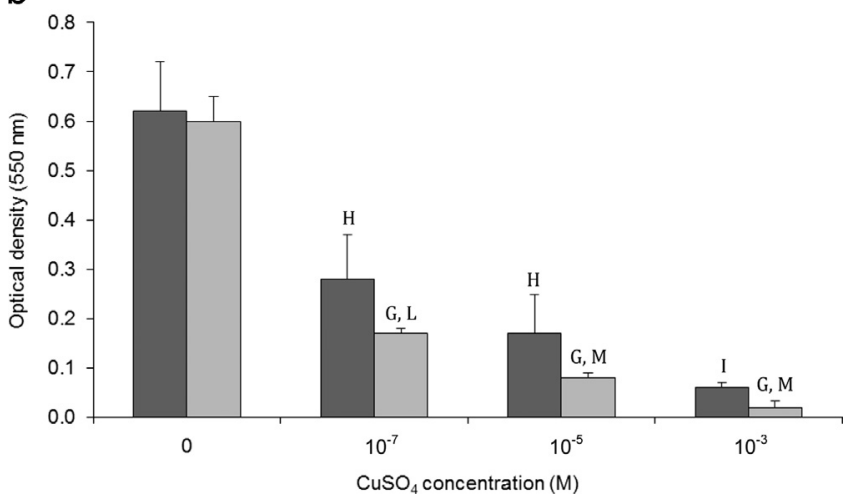

Fig. 2. Cytotoxic effects of $\mathrm{CdCl}_{2}(\mathrm{~A})$ and $\mathrm{CuSO}_{4}$ (B) on separated blood leukocytes of D. labrax after $2 \mathrm{~h}(\square)$ and $24 \mathrm{~h}(\square)$ incubation time. The values are expressed as the optical density of MTT at $550 \mathrm{~nm}$. Data are the means of three distinct experiments \pm standard deviation. Statistical analysis by oneway ANOVA with Tukey's post-test. $A=p<0.05$ and $B=p<0.01$ significance degree between $2 \mathrm{~h}$ and $24 \mathrm{~h}$ incubation time; $C=p<0.01$ and $D=p<0.001$ significance degree between control and $\mathrm{CdCl}_{2}$ concentration at $2 \mathrm{~h} ; E=p<0.01$ and $F=\mathrm{p}<0.001$ significance degree between control and $\mathrm{CdCl}_{2}$ concentration at $24 \mathrm{~h} ; \mathrm{G}=p<0.05$ significance degree between $2 \mathrm{~h}$ and $24 \mathrm{~h}$ incubation time for CuSO4; $H=p<0.01$ and $I=p<0.001$ significance degree between control and $\mathrm{CuSO}_{4}$ concentration at $2 \mathrm{~h}$; and $L=p<0.01$ and $M=p<0.001$ significance degree between control and $\mathrm{CuSO}_{4}$ concentration at $24 \mathrm{~h}$.

exposure times ( $p<0.05$ for $2 \mathrm{~h}$ and $p<0.001$ for $24 \mathrm{~h}$ ) at the lowest concentration of the metal $\left(10^{-7} \mathrm{M}\right)$. Indeed, leukocytes exposed for 2 and $24 \mathrm{~h}$ at a concentration of $10^{-7} \mathrm{M}$ of Cu decreased the uptake of neutral red respectively to 1.187 and 0.095 .

\subsection{MTT reduction assay}

The cytotoxic activity of the metals on leukocytes is shown in Fig. 2. The cells treated with $\mathrm{Cd}$ and $\mathrm{Cu}$ resulted in the reduced capability of mitochondria to effect enzymatic conversion of MTT when compared with controls. Cells exposed for $2 \mathrm{~h}$ to $\mathrm{Cd}$ showed a significant difference $(p<0.01)$ of MTT activity index with respect to controls only at a concentration of $10^{-5}$ in which the control index value was reduced from 0.67 to 0.38 (Fig. 2a). After an exposure of $24 \mathrm{~h}$, the cells showed a strong reduction of MTT index $(p<0.001)$ already at the lower concentration of metal $\left(10^{-7} \mathrm{M}\right)$, reducing the index value of the control from 0.65 to 0.18 (Fig. 2a).

The effects of treatment with $\mathrm{Cu}$ are similar to those observed for $\mathrm{Cd}$, but the $\mathrm{Cu}$ seems to be more toxic than the $\mathrm{Cd}$ because $2 \mathrm{~h}$ of treatment at the concentration of $10^{-7} \mathrm{M}$ was already able to decrease the control value of MTT index significantly $(p<0.01)$, from 0.62 to 0.28 .

\subsection{Induction of apoptosis by cadmium and copper}

After treatment with the metals, at the two concentrations and for the two established times, the genomic DNA was extracted from the cells and agarose gel electrophoresis was performed. Non-random DNA fragmentation has been regarded as one of the typical end points of apoptosis (Khodarev et al., 1998). Fig. 3 shows that DNA fragmentation induced by cadmium and copper was time- and dose-dependent. DNA fragmentation appeared only after $24 \mathrm{~h}$ of treatment with the highest concentration $\left(10^{-3} \mathrm{M}\right)$ of two metals. No results were evident after $2 \mathrm{~h}$ of incubation (data not shown).

\subsection{Real-time PCR analysis}

The expression of Hsp70 mRNA from cells treated with Cd and $\mathrm{Cu}$ was analyzed through real-time PCR. Fig. 4a indicates that the cells, after an exposure with $\mathrm{Cd}$, at a concentration of $10^{-5} \mathrm{M}$ and after $24 \mathrm{~h}$, show a significant increase in the transcription of mRNA specific for Hsp70 $(2.47, p<0.05)$ compared to the control. The value of transcription, however, at higher concentrations $\left(10^{-3} \mathrm{M}\right)$ for both 2 and $24 \mathrm{~h}$ treatments matched the control values (1.35 and 0.85 respectively) (Fig. 4a).

Fig. $3 \mathrm{~b}$ illustrates that treatment with the $\mathrm{Cu}$ causes an increase in transcription of mRNA specific to Hsp70 for all concentrations used, and already at a concentration of $10^{-5} \mathrm{M}$, after $2 \mathrm{~h}$ of treatment, there was a significant increase $(2.8 p<0.01)$ compared to untreated samples (1.1). At higher concentrations $\left(10^{-3} \mathrm{M}\right)$ there was an almost 3-fold increase (2.8) compared to the control (Fig. 3b). After $24 \mathrm{~h}$ treatment it was observed that there was a significant increase of the transcription of mRNA specific for Hsp70 compared to untreated cells both at the lowest concentration $\left(p<0.01,10^{-7} \mathrm{M}\right)$ and at the intermediate concentration $\left(p<0.001,10^{-5} \mathrm{M}\right)$. At the highest concentration $\left(10^{-3} \mathrm{M}\right)$ the values reached those of the control.

\section{Discussion}

Heavy metals, particularly cadmium and copper, have been identified as the major source of aquatic pollution and have been detected in alarming quantities in many water bodies, particularly at or near industrial localities where effluents are routinely discharged. Although there have been marked advances in our understanding of how organic toxic agents can affect living organisms, the mechanisms by which toxic metals such as $\mathrm{Cd}$ or $\mathrm{Cu}$ produce their biochemical effects are still largely unknown (Arizza et al., 2009; Prozialeck, 2000; Prozialeck et al., 2003). Prior to this study, the toxic effects of Cd in fish had been studied in the rainbow trout Oncorhynchus mykiss, specifically for its role in toxicopathological symptoms and bioaccumulation (Battaglini et al., 1993; Kamunde and MacPhail, 2011; Schwartz et al., 2004), and these authors advocated the need to use different fish models for testing metal toxicity. Some studies documented the accumulation of cadmium and copper in the gills, kidneys and liver and the pathological changes of varying severity in the above mentioned organs in sea bass. (Cattani et al., 1996; Giari et al., 2007; Romeo et al., 2000; Viarengo et al., 1997). In this work, we show preliminarily that the cultures of isolated blood leukocytes of D. labrax were able to incorporate $\mathrm{Cd}$ and $\mathrm{Cu}$ after treatment, thus confirming that these metals could cross membranes (for a review see Foulkes (2000)), and accumulate in the cells. In fact, after $24 \mathrm{~h}$ of treatment the concentration was significantly higher. The consequences of the incorporation of cadmium and copper were subsequently evaluated utilizing the NRU and MTT in vitro cytotoxicity assays on separated blood leukocytes. Leukocytes are cells 


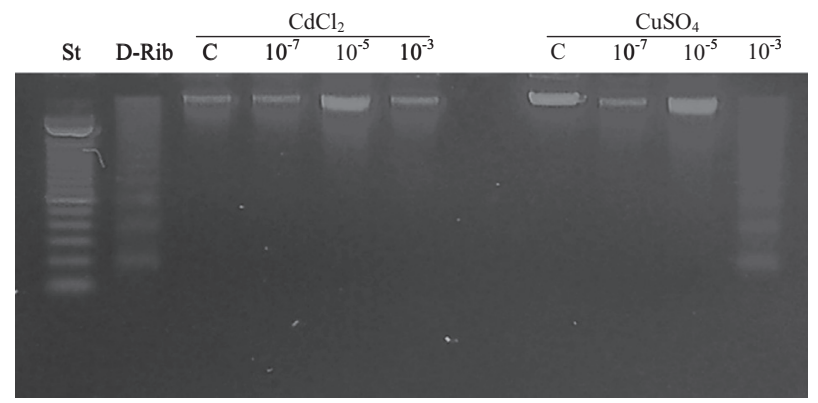

Fig. 3. Agarose gel electrophoresis of genomic DNA from D. labrax enriched leukocytes. The cells were in vitro treated for $24 \mathrm{~h}$ with $10^{-7} \mathrm{M}, 10^{-5} \mathrm{M}$, and $10^{-3} \mathrm{M}$ solutions of $\mathrm{CdCl}_{2}$ or $\mathrm{CuSO}_{4}$. The positive control was performed treating the genomic DNA with $100 \mathrm{mM}$ of 2-deoxy-D-ribosio (D-Rib). St=100 bp DNA ladder marker.
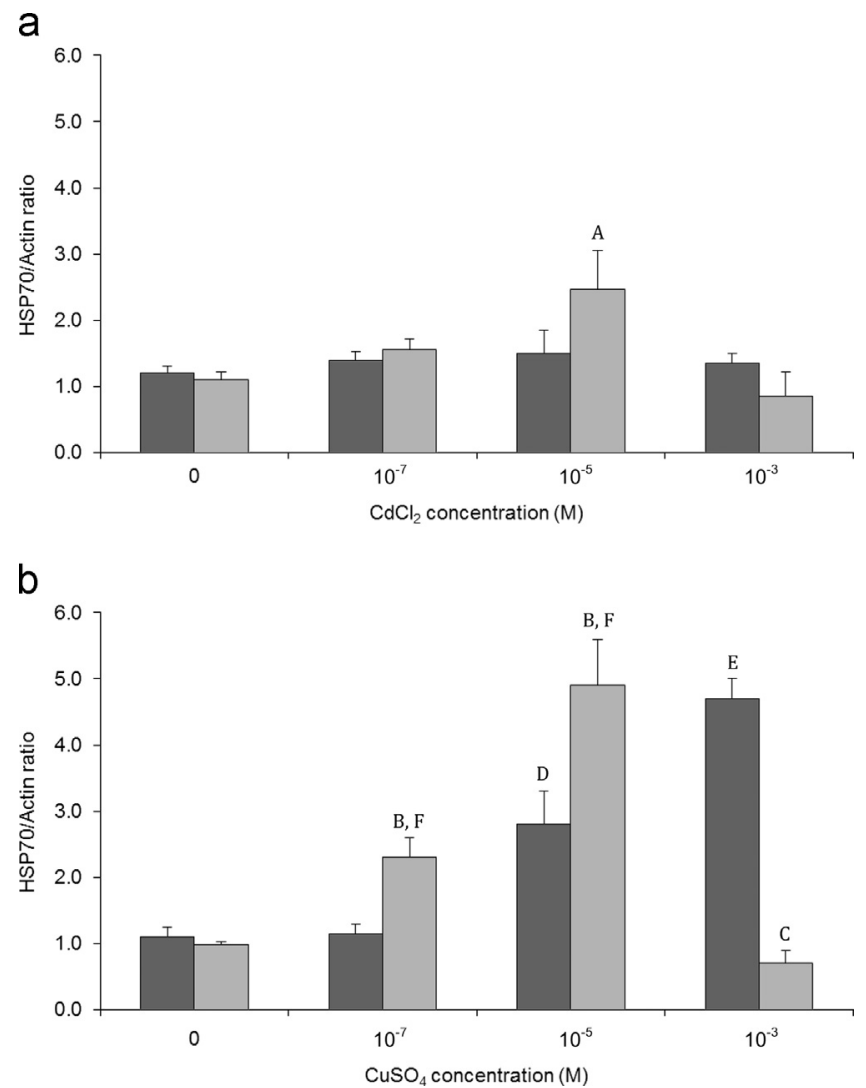

Fig. 4. Expression level of Hsp70 on separated blood leukocytes of D. labrax after $2 \mathrm{~h}(\square)$ and $24 \mathrm{~h}(\square)$ incubation time with $\mathrm{CdCl}_{2}$ (A) and $\mathrm{CuSO}_{4}$ (B). The IDV values were used to express the ratio of Hsp70 mRNA to actin after background correction. Data are the means of three distinct experiments \pm standard deviation. Statistical analysis by one-way ANOVA with Tukey's post-test. $A=p<0.05$ significance degree between control and $\mathrm{CdCl}_{2}$ concentration at $24 \mathrm{~h} ; B=p<0.05$ and $C=p<0.001$ significance degree between $2 \mathrm{~h}$ and $24 \mathrm{~h}$ incubation time for $\mathrm{CuSO}_{4} ; D=p<0.01$ and $E=p<0.001$ significance degree between control and $\mathrm{CuSO}_{4}$ concentration at $2 \mathrm{~h}$; and $F=p<0.01$ significance degree between control and $\mathrm{CuSO}_{4}$ concentration at $24 \mathrm{~h}$.

responsible for a variety of responses of immunity such as phagocytosis, antigen presentation, production of cytokines and the release of anti-microbial and anti-tumor agents. The in vivo modulation of the activity of these cells by environmental factors could have serious consequences on the functioning of the immune system and the organism's resistance to diseases.

Current standard approaches to gauge the degree of cell damage include assays that measure various aspects of cell viability, such as metabolic activity and plasma membrane integrity. The MTT reduction assay, which determines cell metabolic activity, is among the most commonly used end points. This method measures the reduction of MTT salt to a colored insoluble formazan in active mitochondria in viable cells and also, in certain cases, outside the mitochondria (Berridge et al., 2005; Liu et al., 1997). The neutral red uptake (NRU) assay, which is also widely used in biomedical applications, measures the uptake of neutral red dye by viable cells with intact plasma membrane, and its concentration in lysosomes (Repetto et al., 2008).

Our results indicate that the treatment of leukocytes with metals produce a decrease in the uptake of neutral red that is probably caused by a general reduction in lipid membrane stability, which usually precedes cell death (Romeo et al., 2000). The cytotoxic effects of cadmium and copper are reflected in the alteration of the lysosomal membrane, probably due to the high levels of metals that may accumulate in lysosomes rather than being eliminated from the body (Moore, 1990; Regoli, 1992). It is likely that $\mathrm{Cd}$ and $\mathrm{Cu}$ lead to the inhibition of $\mathrm{Mg}^{2+}$-ATPase, a proton pump of lysosomal membranes that maintains the internal environment of lysosomes acid (Lowe et al., 1992). Dysfunction of this ATPase allows the free passage of lysosomal contents, including NRU, into the cytosol (Lowe et al., 1995). In our NRU tests, leukocytes treated with cadmium showed a lower capacity to retain neutral red in the lysosomes. The effects were more pronounced at higher concentrations and for a greater exposure time. However, the effect of cadmium was lower compared with that of copper. Indeed cells exposed to $\mathrm{Cu}$ showed significant reductions in NRU already at $2 \mathrm{~h}$ of treatment and at lower concentrations of the metal $\left(10^{-5} \mathrm{M}\right)$.

To validate the cytotoxicity results obtained by the NRU assay, the cytotoxic sensitivities of the D. labrax leukocyte to the heavy metals were also evaluated using the MTT test, which is known to be more sensitive in detecting early toxicity (Fotakis and Timbrell, 2006) than NRU assays; it is an index of cellular metabolic activity, mainly based on the enzymatic conversion of MTT in the mitochondria. The tetrazole ring of MTT can be reduced by mitochondrial dehydrogenases in formazan if the cells are metabolically active. The data obtained on leukocytes of $D$. labrax show that both 2 and $24 \mathrm{~h}$ after the treatment with both heavy metals $\left(\mathrm{CuSO}_{4}\right.$ and $\mathrm{CdCl}_{2}$ ) there was a constant time-dose dependent decrease of cell viability compared to the control. These data are in agreement with previous work, in particular with a study on six cell lines of fish, in which a time-dose dependent decrease in cell viability following treatment with of $\mathrm{CdCl}_{2}$ and $\mathrm{CuSO}_{4}$ (Tan et al., 2008) was evidenced. The toxicity measured by the MTT was consistent with that obtained by NRU, highlighting the greater impact of copper compared to that of cadmium. Our results seem to be consistent with data present in the literature. In fact similar studies have shown that injecting cadmium or copper into the peritoneal cavity of D. labrax led to a decrease in the stability of the lysosomal membrane of cells of the pronephros, and the impact of copper was greater than that of cadmium (Romeo et al., 2000). The toxic effects of the metals can be produced by an increase of the membrane fluidity leading to a higher rate of fusion of the lysosomes (Moore and Viarengo, 1987). In the digestive gland of mussels submitted to xenobiotic exposure, Moore (1988) reported that enlarged and lipid-enriched lysosomes frequently showed reduced membrane stability, which is indicative of their increased fragility. Metal toxicity may also be exerted through lipid peroxidation, considered as a first step of cellular membrane damage by xenobiotics (Viarengo, 1989). Romeo et al. (2000) showed that lipid peroxidation measured in vitro in the kidney extracts of D. labrax was shown to be higher in the presence of copper than in that of cadmium. Moreover, in the common carp Cyprinus carpio morpha exposed to copper sulfate for $24 \mathrm{~h}$, Radi and Matkovics (1988) found significant increases in the lipid peroxidation measured in the liver, gill and white muscle. 
The cytotoxicity caused by heavy metals may be due to apoptosis. Several reports have shown that cadmium induces apoptosis in various tissues and cells, both in vivo and in vitro (Hamada et al., 1997). E.g., cadmium-induced apoptosis was reported in rat testes (Xu et al., 1996), mouse liver (Habeebu et al., 1998), rat lung epithelial cells (Hart et al., 1999), CL-3 human lung carcinoma cells (Chuang et al., 2000), HeLa human cervix carcinoma cells (Szuster-Ciesielska et al., 2000) and Rat-1 fibroblast cells (Kim et al., 2000). Copper, for its part, can induce an upregulation of apoptosis and related genes in zebrafish (Luzio et al., 2013) or induces the apoptotic cell death in the copepod Tigriopus japonicus (Rhee et al., 2013). Thus in order to assess the phenomenon of apoptosis we examined the integrity of the DNA of leukocytes. During apoptosis, apoptotic cells activate distinct proteases (so-called caspases), and there is also chromatin condensation followed by activation or newly synthesized distinct calcium-dependent nuclease that cuts double-strand DNA at the linker regions between the nucleosomes, resulting in apoptosisspecific DNA fragmentation. The result is electrophoretic separation of apoptotic DNA fragments (multiples of 180-200 bp) corresponding to a typical ladder pattern (Arends et al., 1990). This whole process is triggered by a variety of agents, including calcium ionophores, radiation, heat shock, cytokines, serum deprivation or oxidative stress.

The DNA fragmentation was analyzed using agarose gel electrophoresis 1 percent to demonstrate a "ladder" pattern at $\sim 200$ bp intervals. The DNA extracted from D. labrax leukocytes was perfectly intact at the lower concentrations examined for both treatments with $\mathrm{CuSO}_{4}$ and $\mathrm{CdCl}_{2}$, both at 2 and $24 \mathrm{~h}$. At the highest concentration $\left(10^{-3} \mathrm{M}\right)$ after $24 \mathrm{~h}$ of treatment, a phenomenon detectable with apoptotic DNA fragmentation every $180 \mathrm{bp}$ typical of such an event (Weber and Janz, 2001) was evident. DNA fragmentation which forms a "smear" on agarose gels disclosing necrosis was never found. The cytotoxic effects of $\mathrm{Cd}$ are related to its accumulation in the nucleus by specific metallothioneins and by a strong inhibition effect on superoxide dismutase, peroxidase and catalase, which are major scavenger enzymes of intracellular superoxides. Oxidative stress has been shown to be one of the predominant factors related to apoptosis through peroxinitrite formation (Lin et al., 1997; Stoian et al., 1996; Wolfe et al., 1994). Copper may induce apoptosis through pore formation in the mitochondrial membrane. This would give rise to increased amounts of mitochondrial protein. Among these proteins, there is the EndoG, a mitochondrion-specific nuclease that translocates to the nucleus during cell cycle arrest and apoptosis. Once released from mitochondria, EndoG cleaves chromatin DNA into nucleosomal fragments (independently of caspases); thus, EndoG represents a novel caspase independent apoptotic pathway (Huang et al., 2006; Mitra et al., 2012).

The exposure of organisms to xenobiotics such as heavy metals creates a stress condition that might interfere with the maintenance of homeostasis. Cells respond to stress conditions with a variety of gene families and biochemical pathways that protect and repair them when faced with environmental hazards. Among them there are the heat shock proteins (HSPs): a large group of proteins with a molecular size ranging from $10 \mathrm{kDa}$ to $170 \mathrm{kDa}$. They play a predominant role in chaperoning the folding and/or degradation of proteins (Young et al., 2004) and are highly conserved through evolution, and Hsp70 and Hsp90 have been found in all organisms examined (Kiang and Tsokos, 1998). In particular, Hsp70 is the most ubiquitous and universal chaperone family member involving the unfolding/refolding of newly synthesized and damaged proteins as well as the sequestering and breaking down of proteins that are damaged beyond repair (Mayer and Bukau, 2005). Over-expression of several chaperone proteins can facilitate the repair of misfolded proteins or the elimination of aggregated proteins by the ubiquitin-proteasome system (Esser et al., 2004). The increased expression of HSPs in response to $\mathrm{Cd}$ and $\mathrm{Cu}$ were demonstrated in tissues and cells of many organisms and, among the aquatic invertebrates, mainly in sponges, mollusks, arthropods, echinoderms and fish (Cebrian et al., 2006; Clark and Peck, 2009; Dimitriadis et al., 2012; Lauritano et al., 2012; Matranga et al., 2012).

The cell is provided with protection mechanisms that are able, to some extent, to block the adverse effects of heavy metals. Among these there are two classes of anti-stress proteins: the metallothioneins (MTs) and heat shock proteins (HSPs). The MTs are the first defense mechanism against the toxicity of heavy metals, but when metal concentrations reaches high levels and produce protein denaturation, HSPs act to repair the damage (Giudice et al., 1999). To evaluate the expression of Hsp70 after metal treatment, we analyzed the expression of specific mRNA by RT-PCR. The data obtained indicate that separated leukocytes treated with $\mathrm{CdCl}_{2}$ at lower concentrations did not show significant differences between concentrations and treatment time compared to the controls. Only at a $10^{-5} \mathrm{M}$ concentration was there a significant increase, evident only after $24 \mathrm{~h}$ treatment (Fig. 3a). Instead, the cells treated for $2 \mathrm{~h}$ with $\mathrm{CuSO}_{4}$ significantly increased the transcription of mRNA for Hsp70. Our experiments show that at $10^{-5} \mathrm{M}, \mathrm{CuSO}_{4}$ after $24 \mathrm{~h}$ of treatment significantly increased mRNA expression. At a concentration of $10^{-3} \mathrm{M}$, the transcript reaches lower levels compared to control values, and this decrease could coincide with a possible apoptotic phenomenon. This finding is in agreement with Steiner et al. (1998), who showed that the Hsp70 mRNA transcription increased significantly after stress, and they considered that expression a good indicator of stress. The different behavior of the two metals could be due to a higher resistance of cells to $\mathrm{Cd}$ than Cu (Matozzo et al., 2001; Murata et al., 1999; Romeo et al., 2000), rapidly activating several genes involved in defense mechanisms such as MTs. At higher concentrations of $\mathrm{Cd}\left(10^{-3} \mathrm{M}\right)$, the MTs are not able to chelate all $\mathrm{Cd}$ ions and, due to protein denaturation, they may activate the transcription of HSPs.

\section{Conclusions}

The results of the present study shows that exposure of the leukocytes from the blood of $D$. labrax to $\mathrm{Cu}$ and $\mathrm{Cd}$ may influence the functional responses of cells.

The integrity of the immune system is fundamental for the preservation of homeostasis and the defense against fish pathogens (parasites, bacteria, and viruses). Leukocytes are part of the immune system and are involved in a variety of immunity responses such as phagocytosis, antigen presentation, production of cytokines and the release of anti-microbial and anti-cancer agents. Therefore, the complex network of immune cells regulated by a variety of multistep control processes of cellular interactions could be impaired in one or more steps by pollutants. In fact, the alteration of activity of these cells caused by environmental factors could have serious consequences for the functioning of the organism's immune system and resistance to disease. Therefore, the study of the biochemical parameters that here we have considered could be useful for biomonitoring marine coastal environments.

\section{Funding}

Funds ("ex. 60 percent") were provided by Italian Minister of University, Research and Public Instruction (MIUR) to M. Vazzana. 


\section{Acknowledgments}

We are gratefully to Dr. Benedetto Savona for the help in statistical analysis.

\section{References}

Alyakoob, S., Bouolayan, A.H., Bahloul, M., 1994. Trace metals in gills of fish from the Arabian Gulf. Bull. Environ. Contam. Toxicol. 53, 718-725.

Anderson, D.P., Dixon, O.W., Bodammer, J.E., Lizzio, E.F., 1989. Suppression of antibody-producing cells in rainbow trout spleen sections exposed to copper in vitro. J. Aquat. Anim. Health 1, 57-61.

Arends, M.J., Morris, R.G., Wyllie, A.H., 1990. Apoptosis. The role of the endonuclease. Am. J. Pathol. 136, 593-608.

Arizza, V., Di Fazio, G., Celi, M., Parrinello, N., Vazzana, M., 2009. Cadmium, copper and tributyltin effects on fertilization of Paracentrotus lividus (Echinodermata). Italian. J. Anim. Sci. 8, 839-841.

Arizza, V. Vazzana, M., Schillaci, D, Russo, D., Giaramita, FT, Parrinello, N., 2013. Gender differences in the immune system activities of sea urchin Paracentrotus lividus. Comp. Biochem. Physiol. A Mol. Integr. Physiol. 164, 447-455.

Atif, F., Parvez, S., Pandey, S., Ali, M., Kaur, M., Rehman, H., Khan, H.A., Raisuddin, S. 2005. Modulatory effect of cadmium exposure on deltamethrin-induced oxidative stress in Channa punctata Bloch. Arch. Environ. Contam. Toxicol. 49, 371-377.

Battaglini, P., Andreozzi, G., Antonucci, R., Arcamone, N., Degirolamo, P., Ferrara, L Gargiulo, G., 1993. The effects of cadmium on the gills of the goldfish Carassius auratus L - metal uptake and histochemical changes. Comp. Biochem. Physiol. C Pharmacol. 104, 239-247.

Bennani, N., Schmid-Alliana, A., Lafaurie, M., 1996. Immunotoxic effects of copper and cadmium in the sea bass Dicentrarchus labrax. Immunopharmacol. Immunotoxicol. 118, 129-144.

Berridge, M.V., Herst, P.M. Tan, A.S., 2005. Tetrazolium dyes as tools in cell biology: new insights into their cellular reduction. Biotechnol. Annu. Rev. 11, 127-152.

Borenfreund, E., Puerner, J.A., 1985. Toxicity determined in vitro by morphological alterations and neutral red absorption. Toxicol. Lett. 24, 119-124.

Carvalho, C.S., Fernandes, M.N., 2006. Effect of temperature on copper toxicity and hematological responses in the neotropical fish Prochilodus scrofa at low and high pH. Aquaculture 251, 109-117.

Cattani, O., Serra, R., Isani, G., Raggi, G., Cortesi, P. Carpene, E., 1996. Correlation between metallothionein and energy metabolism in sea bass, Dicentrarchus labrax, exposed to cadmium. Comp. Biochem. Physiol. C Pharmacol. Toxicol. Endocrinol. 113, 193-199.

Cebrian, E., Agell, G., Martí, R., Uriz, M.J., 2006. Response of the Mediterranean sponge Chondrosia reniformis Nardo to copper pollution. Environ. Pollut. 141, 452-458.

Celi, M. Vazzana, M., Salerno, G. Di Bella, M.L, Arizza, V., Parrinello, N, 2008. Effects of cadmium on expression of the Hsp70 in sea bass (Dicentrarchus labrax L., Osteichthyes. Moronidae) blood cells. Biol. Mar. Mediterr. 15, 2.

Celi, M., Vazzana, M., Sanfratello, M.A., Parrinello, N., 2012. Elevated cortiso modulates Hsp70 and Hsp90 gene expression and protein in sea bass head kidney and isolated leukocytes. Gen. Comp. Endocrinol. 175, 424-431.

Chuang, S.M., Wang, I.C., Yang, J.L., 2000. Roles of JNK, p38 and ERK mitogenactivated protein kinases in the growth inhibition and apoptosis induced by cadmium. Carcinogenesis 21, 1423-1432.

Clark, M.S., Peck, L.S., 2009. Hsp70 heat shock proteins and environmental stress in antarctic marine organisms: a mini-review. Mar. Genom. 2, 11-18.

Dick, P.T., Dixon, D.G., 1985. Changes in circulating blood cell levels of rainbow trout, Salmo gairdneri Richardson, following acute and chronic exposure to copper. J. Fish Biol. 26, 475-481.

Dimitriadis, V.K. Gougoula, C. Anestis, A., Pörtner, H.O. Michaelidis, B., 2012 Monitoring the biochemical and cellular responses of marine bivalves during thermal stress by using biomarkers. Mar. Environ. Res. 73, 70-77.

Elsasser, M.S., Roberson, B.S., Hetrick, F.M., 1986. Effects of metals on the chemiluminescent response of rainbow trout (Salmo gairdneri) phagocytes. Vet. Immunol. Immunopathol. 12, 243-250.

Emmanouil, C., Sheehan, T.M., Chipman, J.K., 2007. Macromolecule oxidation and DNA repair in mussel (Mytilus edulis L.) gill following exposure to $\mathrm{Cd}$ and $\mathrm{Cr}(\mathrm{VI})$. Aquat. Toxicol. 82, 27-35.

Esser, C., Alberti, S., Hohfeld, J., 2004. Cooperation of molecular chaperones with the ubiquitin/proteasome system. Biochim. Biophys. Acta 1695, 171-188.

Fautz, R., Husein, B., Hechenberger, C., 1991. Application of the neutral red assay (NR assay) to monolayer cultures of primary hepatocytes: rapid colorimetric viability determination for the unscheduled DNA synthesis test (UDS). Mutat Res. 253, 173-179.

Fotakis, G., Timbrell, J.A., 2006. In vitro cytotoxicity assays: comparison of LDH, neutral red, MTT and protein assay in hepatoma cell lines following exposure to cadmium chloride. Toxicol. Lett. 160, 171-177.

Foulkes, E.C., 2000. Transport of toxic heavy metals across cell membranes. Proc. Soc. Exp. Biol. Med. 223, 234-240.

Giari, L., Manera, M., Simoni, E., Dufuli, B.S., 2007. Cellular alterations in different organs of european sea bass Dicentrarchus labrax (L.) exposed to cadmium. Chemosphere 67, 1171-1181.
Giudice, G., Sconzo, G., Roccheri, M.C., 1999. Studies on heat shock proteins in sea urchin development. Dev, Growth Differ: 41, 375-380.

Habeebu, S.S., Liu, J., Klaassen, C.D., 1998. Cadmium induced apoptosis in mouse liver. Toxicol. Appl. Pharmacol. 149, 203-209.

Hamada, T., Tanimoto, A., Sasaguri, Y., 1997. Apoptosis induced by cadmium. Apoptosis 2, 359-367.

Hart, B.A., Lee, C.H., Shukla, G.S., Shukla, A., Osier, M., Eneman, J.D., Chiu, J.F., 1999. Characterization of cadmium induced apoptosis in rat lung epithelial cells: evidence for the participation of oxidant stress. Toxicology 133, 43-58.

Huang, K.J., Ku, C.C., Lehman, I.R., 2006. Endonuclease G: a role for the enzyme in recombination and cellular proliferation. Proc. Natl. Acad. Sci. USA 103, 8995-9000.

Joseph, P., 2009. Mechanisms of cadmium carcinogenesis. Toxicol. Appl. Pharmacol. 238, 272-279.

Kamunde, C., MacPhail, R., 2011. Subcellular interactions of dietary cadmium, copper and zinc in rainbow trout (Oncorhynchus mykiss). Aquat. Toxicol. 105, $518-527$.

Khodarev, N.N., Sokolova, I.A., Vaughan, A.T., 1998. Mechanisms of induction of apoptotic DNA fragmentation. Int. J. Radiat. Biol. 73, 455-467.

Kiang, J.G., Tsokos, G.C., 1998. Heat shock protein 70 kDa: molecular biology, biochemistry, and physiology. Pharmacol. Ther. 80, 183-201.

Kim, M.S., Kim, B.J., Woo, H.N., Kim, K.W., Kim, K.B., Kim, I.K., Jung, Y.K., 2000. Cadmium induces caspase-mediated cell death: suppression by Bcl-2. Toxicology $145,27-37$.

Lauritano, C., Procaccini, G., Ianora, A., 2012. Gene expression patterns and stress response in marine copepods. Mar. Environ. Res. 76, 22-31.

Lemairegony, S., Lemaire, P., Pulsford, A.L., 1995. Effects of cadmium and benzo(a) pyrene on the immune system, gill atpase and erod activity of european sea bass Dicentrarchus labrax. Aquat. Toxicol. 31, 297-313.

Lin, K.T., Xue, J.Y., Sun, F.F., Wong, P.Y., 1997. Reactive oxygen species participate in peroxynitrite-induced apoptosis in HL-60 cells. Biochem. Biophys. Res. Commun. 230, 115-119.

Liu, Y., Peterson, D.A., Kimura, H., Schubert, D., 1997. Mechanism of cellular 3-(4,5dimethylthiazol-2-yl)-2,5-diphenyltetrazolium bromide (MTT) reduction. J. Neurochem. 69, 581-593.

Lowe, D.M., Fossato, V.U., Depledge, M.H., 1995. Contaminant-induced lysosomal membrane damage in blood cells of mussels Mytilus galloprovincialis from the Venice lagoon: an in vitro study. Mar. Ecol. Prog. Ser. 129, 189-196.

Lowe, D.M., Moore, M.N., Evans, B.M., 1992. Contaminant Impact on Interactions of molecular probes with lysosomes in living hepatocytes from dab Limanda limanda. Mar. Ecol. Prog. Ser. 91, 135-140.

Luzio, A., Monteiro, S.M., Fontaínhas-Fernandes, A.A., Pinto-Carnide, O., Matos, M., Coimbra, A.M., 2013. Copper induced upregulation of apoptosis related genes in zebrafish (Danio rerio) gill. Aquat. Toxicol. 128-129, 183-189.

Malagoli, D., Iacconi, I., Marchesini, E., Ottaviani, E., 2005. Cell-death mechanisms in the IPLB-LdFB insect cell line: a nuclear located Bcl-2-like molecule as a possible controller of 2-deoxy-D-ribose-mediated DNA fragmentation. Cell Tissue Res. 320, 337-343.

Matozzo, V., Ballarin, L., Pampanin, D.M., Marin, M.G., 2001. Effects of copper and cadmium exposure on functional responses of hemocytes in the clam, Tapes philippinarum. Arch. Environ. Contam. Toxicol. 41, 163-170.

Matranga, V., Pinsino, A., Randazzo, D., Giallongo, A., Dubois, P., 2012. Long-term environmental exposure to metals $(\mathrm{Cu}, \mathrm{Cd}, \mathrm{Pb}, \mathrm{Zn})$ activates the immune cell stress response in the common European sea star (Asterias rubens). Mar. Environ. Res. 76, 122-127.

Mayer, M.P., Bukau, B., 2005. Hsp70 chaperones: cellular functions and molecular mechanism. Cell. Mol. Life Sci. 62, 670-684.

Mitra, S., Keswani, T., Dey, M., Bhattacharya, S., Sarkar, S., Goswami, S., Ghosh, N. Dutta, A., Bhattacharyya, A., 2012. Copper-induced immunotoxicity involves cell cycle arrest and cell death in the spleen and thymus. Toxicology 293, 78-88.

Moore, M.N., 1988. Cytochemical responses of the lysosomal system and NADPHferrihemoprotein reductase in molluscan digestive cells to environmental and experimental exposure to xenobiotics. Mar. Ecol. Prog. Ser. 46, 81-89.

Moore, M.N., 1990. Lysosomal cytochemistry in marine environmental monitoring. Histochem. J. 22, 187-191.

Moore, M.N., Viarengo, A., 1987. Lysosomal membrane fragility and catabolism of cytosolic proteins: evidence for a direct relationship. Experientia 43, 320-323.

Morgan, C.D., Mills, K.C., Lefkowitz, D.L., Lefkowitz, S.S., 1991. An improved colorimetric assay for tumor necrosis factor using Wehi 164 cells cultured on novel microtiter plates. J. Immunol. Methods 145, 259-262.

Mosmann, T., 1983. Rapid colorimetric assay for cellular growth and survival: application to proliferation and cytotoxicity assays. J. Immunol. Methods 65, 55-63.

Murad, A., Houston, A.H., 1988. Leukocytes and leukopoietic capacity in goldfish, Carassius auratus, exposed to sublethal levels of cadmium. Aquat. Toxicol. 13, $141-154$.

Murata, M., Gong, P., Suzuki, K., Koizumi, S., 1999. Differential metal response and regulation of human heavy metal-inducible genes. J. Cell. Physiol. 180, 105-113.

Nussey, G., Vanvuren, J.H.J., Dupreez, H.H., 1995. Effect of copper on the differential white blood-cell counts of the Mozambique tilapia (Oreochromis mossambicus). Comp. Biochem. Physiol. C Pharmacol. Toxicol. Endocrinol. 111, 381-388.

O'Neill, J.G., 1981. The humoral immune response of Salmo trutta L. and Cyprinus carpio L. exposed to heavy metals. J. Fish Biol. 19, 10.

Prozialeck, W.C., 2000. Evidence that E-cadherin may be a target for cadmium toxicity in epithelial cells. Toxicol. Appl. Pharmacol. 164, 231-249.

Prozialeck, W.C., Lamar, P.C., Lynch, S.M., 2003. Cadmium alters the localization of $\mathrm{N}$-cadherin, E-cadherin, and beta-catenin in the proximal tubule epithelium. Toxicol. Appl. Pharmacol. 189, 180-195. 
Pruski, A.M., Dixon, D.R., 2002. Effects of cadmium on nuclear integrity and DNA repair efficiency in the gill cells of Mytilus edulis L. Aquat. Toxicol. 57, 127-137.

Qian, Z., Liu, X., Wang, L., Wang, X., Li, Y., Xiang, J., Wang, P., 2012. Gene expression profiles of four heat shock proteins in response to different acute stresses in shrimp, Litopenaeus vannamei. Comp. Biochem. Physiol. C Toxicol. Pharmacol. 156, 211-220.

Radi, A.A., Matkovics, B., 1988. Effects of metal ions on the antioxidant enzyme activities, protein contents and lipid peroxidation of carp tissues. Comp. Biochem. Physiol. C. 90, 69-72.

Regoli, F., 1992. Lysosomal responses as a sensitive stress Index in biomonitoring heavy-metal pollution. Mar. Ecol. Prog. Ser. 84, 63-69.

Repetto, G., del Peso, A., Zurita, J.L., 2008. Neutral red uptake assay for the estimation of cell viability/cytotoxicity. Nat. Protoc. 3, 1125-1131.

Rhee, J.S., Yu, I.T., Kim, B.M., Jeong, C.B., Lee, K.W., Kim, M.J., Lee, S.J., Park, G.S., Lee, J. S., 2013. Copper induces apoptotic cell death through reactive oxygen speciestriggered oxidative stress in the intertidal copepod Tigriopus japonicus. Aquat. Toxicol. 132-133, 182-189.

Romeo, M., Bennani, N., Gnassia-Barelli, M., Lafaurie, M., Girard, J.P., 2000. Cadmium and copper display different responses towards oxidative stress in the kidney of the sea bass Dicentrarchus labrax. Aquat. Toxicol. 48, 185-194.

Said Ali, K., Ferencz, A., Nemcsok, J., Hermesz, E., 2010. Expressions of heat shock and metallothionein genes in the heart of common carp (Cyprinus carpio): effects of temperature shock and heavy metal exposure. Acta Biol. Hung. 61, $10-23$.

Sanchez-Dardon, J., Voccia, I., Hontela, A., Chilmonczyk, S., Dunier, M., Boermans, H., Blakley, B., Fournier, M., 1999. Immunomodulation by heavy metals tested individually or in mixtures in rainbow trout (Oncorhynchus mykiss) exposed in vivo. Environ. Toxicol. Chem. 18, 1492-1497.

Schwartz, M.L., Curtis, P.J., Playle, R.C., 2004. Influence of natural organic matter source on acute copper, lead, and cadmium toxicity to rainbow trout (Oncorhynchus mykiss). Environ. Toxicol. Chem. 23, 2889-2899.

Steiner, E., Kleinhappl, B., Gutschi, A., Marth, E., 1998. Analysis of Hsp70 mRNA levels in HepG2 cells exposed to various metals differing in toxicity. Toxicol. Lett. 96-97, 169-176.

Stoian, I., Oros, A., Moldoveanu, E., 1996. Apoptosis and free radicals. Biochem. Mol. Med. 59, 93-97.
Szuster-Ciesielska, A., Stachura, A., Slotwinska, M., Kaminska, T., Sniezko, R., Paduch, R., Abramczyk, D., Filar, J., Kandefer-Szerszen, M., 2000. The inhibitory effect of zinc on cadmium-induced cell apoptosis and reactive oxygen species (ROS) production in cell cultures. Toxicology 145, 159-171.

Tan, F., Wang, M., Wang, W., Lu, Y., 2008. Comparative evaluation of the cytotoxicity sensitivity of six fish cell lines to four heavy metals in vitro. Toxicol. In Vitro 22, 164-170.

Thophon, S., Kruatrachue, M., Upatham, E.S., Pokethitiyook, P., Sahaphong, S. Jaritkhuan, S., 2003. Histopathological alterations of white seabass, Lates calcarifer, in acute and subchronic cadmium exposure. Environ. Pollut. 121, 307-320.

Thuvander, A., 1989. Cadmium exposure of rainbow trout, Salmo gairdneri Richardson - effects on immune functions. J. Fish Biol. 35, 521-529.

Vazzana, M., Parrinello, D., Cammarata, M., 2003. Chemiluminescence response of beta-glucan stimulated leukocytes isolated from different tissues and peritoneal cavity of Dicentrarchus labrax. Fish Shellfish Immunol. 14, 423-434.

Vazzana, M., Salerno, G., Celi, M., Vizzini, A., Parrinello, D., Di Bella, M.L., Arizza, V. 2009. Effect of in vitro exposure to cadmium and copper on sea bass blood cells. Italian J. Anim. Sci. 8, 884-886.

Viarengo, A., 1989. Molecular mechanisms of heavy metal cytotoxicity in marine organisms. Mar. Environ. Res. 28, 298.

Viarengo, A., Bettella, E., Fabbri, R., Burlando, B., Lafaurie, M., 1997. Heavy metal inhibition of EROD activity in liver microsomes from the bass Dicentrarchus labrax exposed to organic xenobiotics: role of GSH in the reduction of heavy metal effects. Mar. Environ. Res. 44, 1-11.

Weber, L.P., Janz, D.M., 2001. Effect of beta-naphthoflavone and dimethylbenz[a] anthracene on apoptosis and Hsp70 expression in juvenile channel catfish (Ictalurus punctatus) ovary. Aquat. Toxicol. 54, 39-50.

Wolfe, J.T., Ross, D., Cohen, G.M., 1994. A role for metals and free radicals in the induction of apoptosis in thymocytes. FEBS Lett. 352, 58-62.

Xu, C., Johnson, J.E., Singh, P.K., Jones, M.M., Yan, H., Carter, C.E., 1996. In vivo studies of cadmium-induced apoptosis in testicular tissue of the rat and its modulation by a chelating agent. Toxicology 107, 1-8.

Young, J.C., Agashe, V.R., Siegers, K., Hartl, F.U., 2004. Pathways of chaperonemediated protein folding in the cytosol. Nat. Rev. Mol. Cell Biol. 5, 781-791.

Zelikoff, J.T., 1993. Metal pollution-induced immunomodulation in fish. Annu. Rev. Fish Dis. 3, 305-325. 